\title{
ECOLOGY AND STRUCTURE OF DROSOPHYLLUM LUSITANICUM (L.) LINK POPULATIONS IN THE SOUTH- WESTERN OF THE IBERIAN PENINSULA
}

\author{
Jonas MÜLLER \& Ulrich DEIL
}

\begin{abstract}
Ecology and structure of Drosophyllum lusitanicum (L.) Link populations in the southwestern of the Iberian Peninsula. The population size and the demographic structure of the autogamous and nautochoric Drosophyllum lusitanicum were studied in two areas in the South-western Iberian Peninsula. Its coenological character is documented by a synoptic phytosociological table, based upon the published relevés and new data. In the Serra de Monchique (Portugal), the distribution was mapped. 21 populations are growing there with an average size of 165 individuals. In the Campo de Gibraltar (Spain), the biggest population with several thousands of individuals occurs in the Sierra del Aljibe. Plant size, rosette diameter and lignification rate from 700 measured individuals are used as indirect indicators for the age-structure in 19 populations.

Drosophyllum has a certain pioneer character. It occurs mostly in open Ericion umbellatae-heathland communities (Stauracantho-Drosophylletum, Querco lusitanicae-Stauracanthetum, Genisto tridentisStauracanthetum etc.). It is able to colonize disturbed habitats like roadside verges and fire prevention strips and is an apophyt in the Drosophyllo-[Stauracanthenion]-basal community. As a re-seeder the species is favoured by fire events of medium frequency. In open Myrto-Quercetum suberis-woodland and in dense Erica australis-heathland, large and tall-growing specimens predominate; there the populations are over-aged. Some deficits in the knowledge of its reproductive biology and further research topics are outlined and the needs for conservation efforts in the Portuguese study area are strengthened.
\end{abstract}

Key words. Heathland vegetation, Ericion umbellatae, Portugal, Serra de Monchique, Spain, phytosociology, endemism.

RESUMEN. Ecología y estructura de poblaciones de Drosophyllum lusitanicum (L.) Link en el suroeste de la Península Ibérica. Drosophyllum lusitanicum es una planta autógama y nautocórica cuyo tamaño y estructura de población han sido estudiados en dos áreas del suroeste de la Península Ibérica. Su carácter cenológico se documenta mediante una tabla fitosociológica sintética basada en inventarios ya publicados y datos nuevos. En la Sierra de Monchique (Portugal) se cartografían 21 poblaciones cuyo tamaño medio es de 165 individuos. Sin embargo, en el Campo de Gibraltar (España), se encontró la población de mayor tamaño, con varios miles de individuos en la Sierra del Aljibe. Aquí se estudió el tamaño de las plantas, el diámetro de la roseta basal y el grado de lignificación de 700 individuos, lo que se utilizó como indicador indirecto de la estructura de edades de 19 poblaciones.

Drosophyllum lusitanicum tiene un cierto carácter pionero. Se presenta mayoritariamente en los brezales aclarados de Ericion umbellatae (Stauracantho-Drosophylletum, Querco lusitanicaeStauracanthetum, Genisto tridentis-Stauracanthetum, etc.). Es capaz de colonizar medios alterados, como cunetas de carreteras y cortafuegos, y es un apófito en las comunidades basales de Drosophyllo[Stauracanthenion], siendo además esta especie favorecida por los frecuentes incendios de la zona. En los alcornocales abiertos de Myrto-Quercetum suberis y en los brezales densos de Erica australis predominan 
los individuos grandes, siendo éstas poblaciones maduras. Finalmente, se aportan algunos datos poco conocidos de su reproducción y ecología que indican la necesidad de un mayor esfuerzo para la conservación del área portuguesa estudiada.

Palabras clave. Brezales, Ericion umbellatae, Portugal, Serra de Monchique, España, fitosociología, endemismos.

\section{INTRODUCTION}

Unlike the Calluno-Ulicetea-heathland in the perhumid climate of Western Europe, dominated by eurychorous taxa, the heathland associations of the suballiance Stauracanthenion boivinii (Ericion umbellatae, Calluno-Ulicetea), distributed in the mountainous arc from the Serra de Monchique in Southern Portugal via the Sierras de Algeciras (SW Spain) to the Western Rif Mountains (Morocco), are characterized by a remarkable degree of endemism and species richness (Arroyo \& Marañón, 1990; Galán de Mera \& Vicente Orellana, 1996; Ojeda et al., 1995, 1996a). One reason might be that this southwestern part of the Mediterranean region is a centre of origin of this type of vegetation. The occurrence of heliophilous low shrub endemics like Drosophyllum lusitanicum, Nothobartsia aspera, Odontites foliosa, Teucrium afrum ssp. rubriflorum etc. indicate that there exist - at least in small areas primary habitats for those characteristic heathland species.

In their area of distribution, however, Calluno-Ulicetea-communities must be considered as secondary (man-made) communities in most cases, replacing acidophilous forests (mostly cork-oak forests) after cutting and burning. During the last few decades, the heathlands in Southern Portugal and in Andalusia were affected by severe landuse changes. Some major trends are the decline or even the total abandonment of traditional rotating cultivation practises, a decreasing grazing impact, the afforestation with allochtone taxa like Eucalyptus and Pinus and the change of fire frequency and intensity (Krohmer \& Deil, 1999). Are the Stauracanthenion-species threatened or favoured by these current land-use trends?

A first step to answer this question is to have a closer look upon the ecological requirements and coenological value of keystone species in primary and secondary habitats, and to study their life cycle and population structure in different situations. One of those southwest-Iberian-northwestMoroccan elements, upon which the phytogeographical province Tingitano-OnuboAlgarviense within the superprovince Iberomarroquí-atlántica (Galán de Mera \& Vicente Orellana, 1996; Pérez Latorre et al., 1996) is based, is Drosophyllum lusitanicum (L.) Link. It is a carnivorous, low growing perennial plant, lignified in its basal shoots (half shrub, chamaephytic growth from). This monotypic genus has quite an isolated position within the Droseraceae-family and is sometimes even separated from Droseraceae as the monospecific family Drosophyllaceae (Williams et al., 1994). It shares its distribution, sociology, life form, and isolated taxonomic position with the still rarer Nothobartsia aspera (for the latter species see Galán de Mera et al., 1996).

Most of the populations of Drosophyllum lusitanicum are located near the sea (fig. 1). They range from Northern Portugal along the Atlantic coast to the Serra de Monchique in the Algarve Hinterland. In Spain, the highest density of populations can be found in the Campo de Gibraltar (Aljibian sector of the 


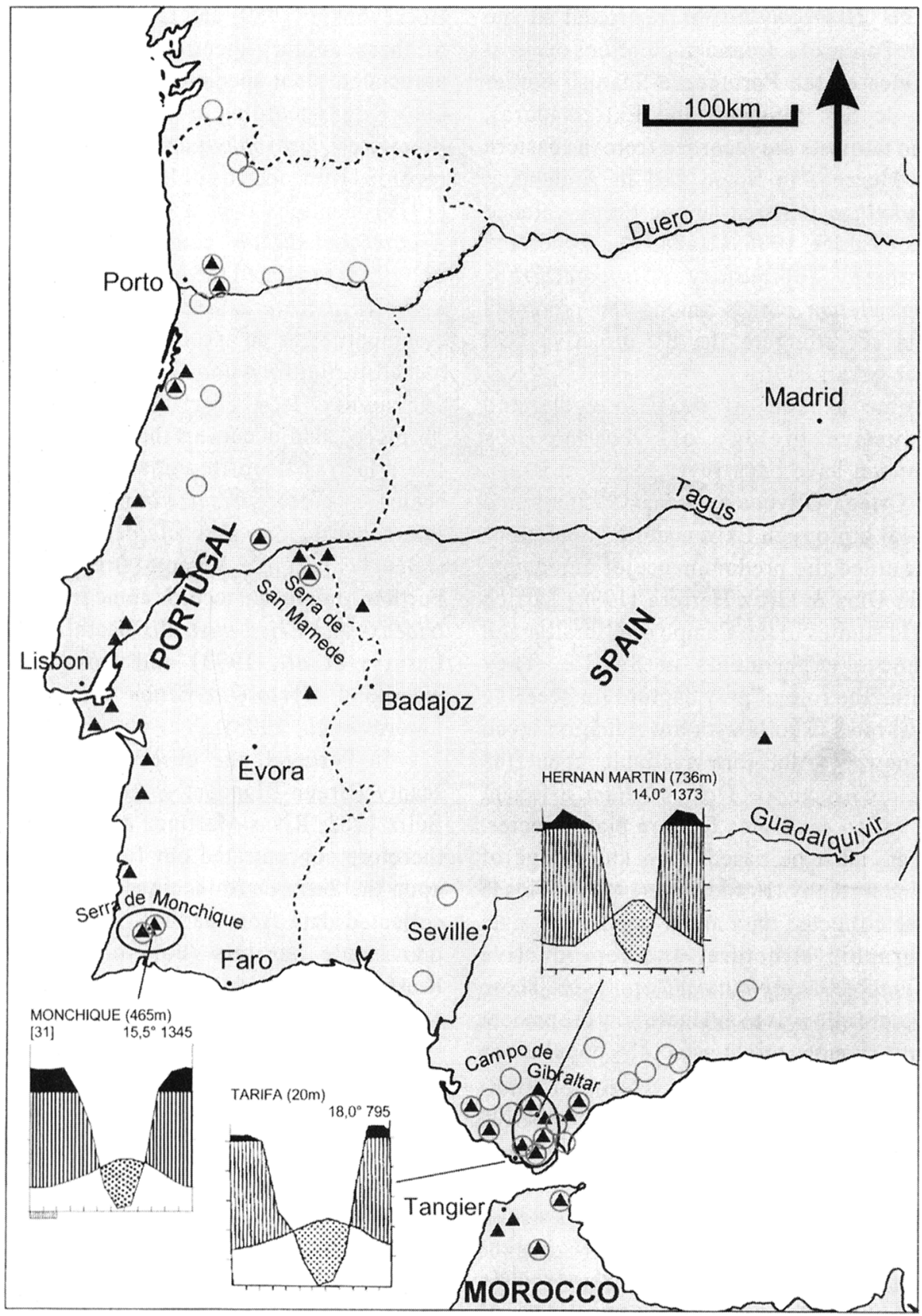

Figure 1. Study areas (black ellipses), distribution of Drosophyllum lusitanicum ( $\mathbf{\Delta}$ ), and locations of phytosociological relevés $(O)$ (after our own data and various authors). 
Tingitano-Onubo-Algarvian province). In Morocco, Drosophyllum is restricted to the Tangier Peninsula. Inland populations occur at both sides of the Portuguese-Spanish border (Serra de San Mamede and Extremadura), isolated outposts are recorded from the eastern Sierra Morena. In Spain and in Andalusia, Drosophyllum is listed among the threatened species (Valdés, 1996; Ocaña et al. 2000) and the plant community StauracanthoDrosophylletum ranges among the protected habitats according to the EU-directive (Gil Jiménez et al., 1996).

Some aspects of the life cycle and reproductive biology of Drosophyllum lusitanicum have been investigated in recent years. Ortega Olivencia et al. (1995) studied the floral biology in Extremadura populations and recorded the predominance of autogamy. Garrido Díaz \& Ortiz Herrera (1996) carried out field studies in the Campo de Gibraltar and glasshouse experiments in Seville. They underline the role of prey capture for seedling survival rates in soils with low nutrition level. Until now, no data are available about the population structure of Drosophyllum. Efficient conservation strategies for rare plant species, however, must be based upon knowledge of their demography (Holderegger, 1996). This is why we collected data about population size, demographic structure, and reproductive behaviour of Drosophyllum lusitanicum. These data should allow us to evaluate how the present land-use changes might affect the populations of this species in the future.

To answer the questions, what are the primary respectively the secondary habitats of Drosophyllum lusitanicum and in which plant communities does it occur, we present a synoptic view of the available plant sociological studies and gathered new data from Southern Portugal. Populations of Drosophyllum in pine and cork-oak woodlands are recorded by Ortega Olivencia et al. (1995); herbarium records from clearings and in coastal rock communities are presented by Boesewinkel (1989) and Cheers (1992). None of these authors mention the whole set of associated plant species. What is the state of knowledge according to the plant sociological literature?. Drosophyllum lusitanicum is often recorded from open heathland: Rivas-Martínez (1979) mentions it as a character species of Ericion umbellatae- communities. Quézel et al. (1988) separated the open type of the Erica umbellata-Stauracanthus boiviniicommunities as an association of its own and named it Stauracantho-Drosophylletum. This community, first described from Northern Morocco, also occurs in the Cádiz Peninsula (Deil, 1997a). It is differentiated in the Aljibian sector by Satureja salzmanii (DrosophylloStauracanthetum saturejetosum salzmanii, Galán de Mera \& Vicente Orellana, 1996). Further Andalusian records come from Genista tridens- and Erica australis-heathland (Pérez Latorre et al., 1993) and from cork-oak woodland Myrto-Quercetum suberis (Pérez Latorre et al., 1993).

In Portugal, the observations are quite scanty (Braun-Blanquet et al., 1964; Malato Béliz 1982; Rivas-Martínez et al., 1990). We therefore concentrated our field observations upon the Serra de Monchique in Portugal and collected data from natural, seminatural and man made habitats (cork-oak woodland, heathland, roadside verges, fire prevention strips etc.).

\section{THE STUDY AREAS}

Field studies were carried out in two regions located in the southwestern part of the Iberian Peninsula (fig.1): the first study area, the Serra de Monchique, is situated in a mountainous region of mid altitude ( $902 \mathrm{~m}$ a.s.l. at Foia) in the Algarve Hinterland (District of Faro, Portugal). The second study area are the Sierras of the Campo de Gibraltar (Cádiz and 


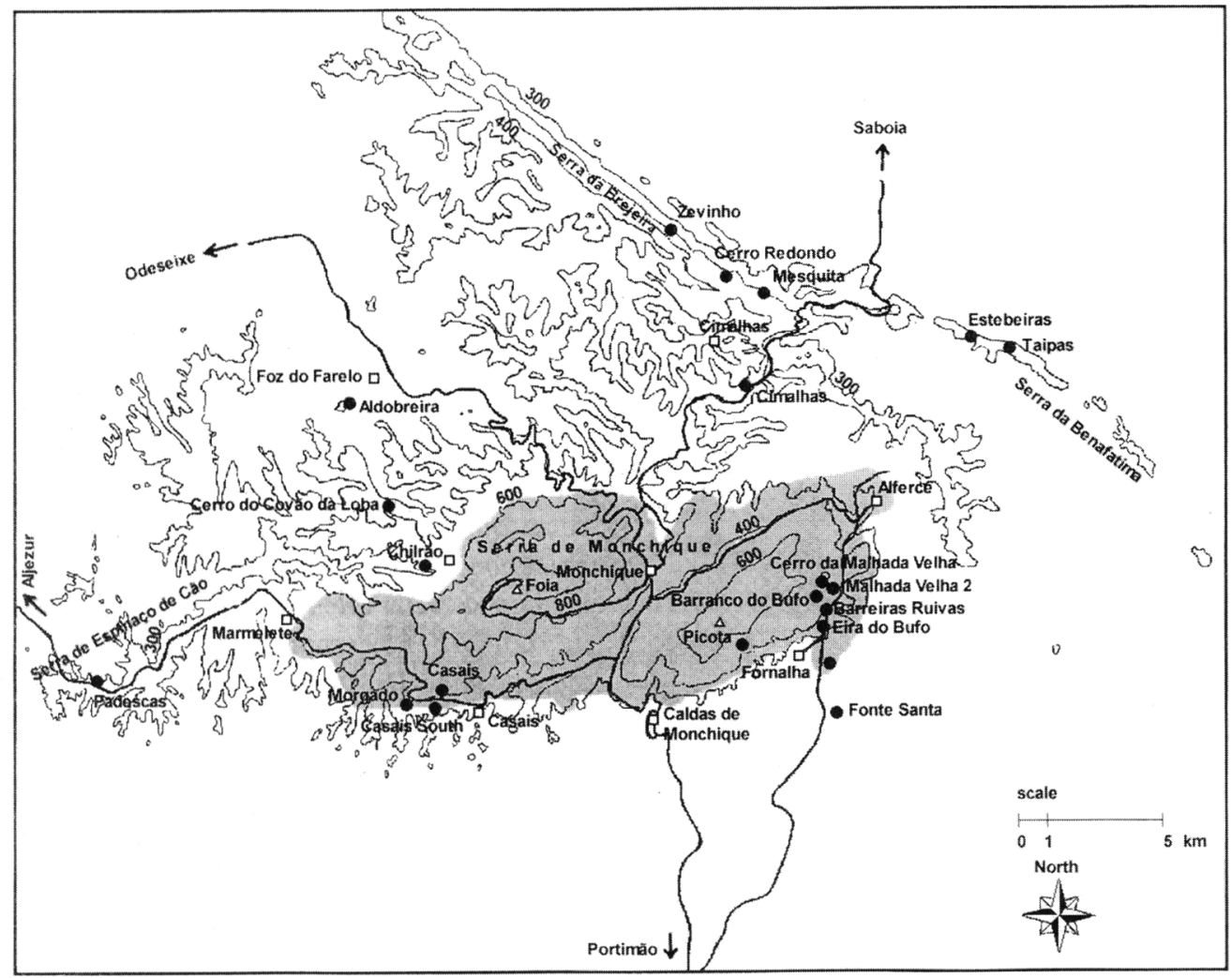

Figure 2. Distribution of Drosophyllum lusitanicum ) in the Serra de Monchique. The syenite area is marked with grey colour.

Málaga provinces, Andalusia, Spain). Both areas have been selected because they shelter important populations of Drosophyllum lusitanicum, they offer quite similar physical conditions and they are subjected to different trends in land-use changes (Deil, 1997a).

The study areas have a Mediterranean climate with Atlantic character (see climatic graphs in figure 1). Westerly winds, high air humidity and frequent clouds in the summit parts reduce the severity of summer drought. The central part of the Serra de Monchique consists of a syenite intrusion, surrounded by Palaeozoic schists and greywakes. The weathering of the coarse-grained syenite results in cambisols with a sandy texture and a high water holding capacity, whereas on the schists stony leptosols with low nutrient content develop. The Sierras of the Campo de Gibraltar are part of the betic-riphaean mountain ridge, consisting of several Cretaceous and Tertiary flysch layers. Most of the Drosophyllumpopulations there grow on sandy soils over Aljibe-sandstone.

The climax community in the thermomediterranean part of the Serra de Monchique is an open cork-oak woodland (Myrto-Quercetum suberis), followed in the 


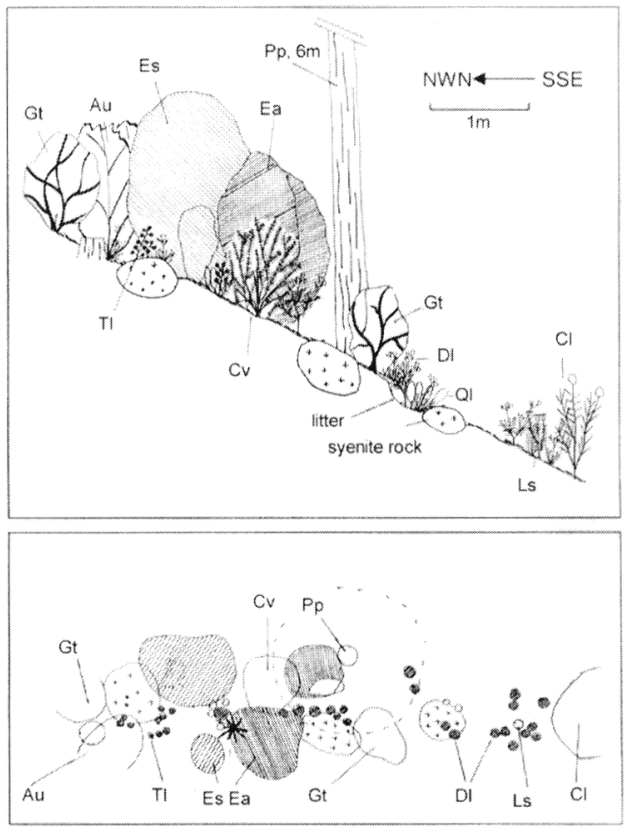

Figure 3. Erico australis-Cistetum populifolii with Drosophyllum lusitanicum. Vertical and horizontal structure of this tall-growing heathland community on a rocky slope near Cerro da Malhada Velha in the Serra de Monchique. Abbreviations: Au: Arbutus unedo, $\mathrm{Cl}$ : Cistus ladanifer, $\mathrm{Cv}$ : Calluna vulgaris, Dl: Drosophyllum lusitanicum, Ea: Erica australis, Es: Erica scoparia, Gt: Genista tridentata, Ls: Lavandula stoechas, Pp: Pinus pinaster, Q1: Quercus lusitanica, Tl: Tuberaria lignosa.

mesomediterranean by dense oak forests (Sanguisorbo-Quercetum suberis typicum in the humid parts and quercetosum canariensis in the hyper-humid parts) (Malato Béliz, 1982; Rivas-Martínez et al., 1990; Seng \& Deil, 1999). The Phillyreo-Arbutetum unedonis as the first degradation step of Quercus suberforests is widespread and traditionally and currently used to harvest fruits from the strawberry tree. Further degradation results in heathland communities. They have expanded under human impact (fire, grazing, cutting) from a few original sites (mountain ridges heavily exposed to wind, rocky outcrops with superficial soils, hyperhumid sites with stagnant water and pseudogley) and currently cover vast areas. The Erica-heathlands and Cistus-shrublands show a clear bioclimatic zonation. There is a transition from CistoLavanduletea in the thermomediterranean, dry and subhumid zone to Calluno-Ulicetea in the mesomediterranean, humid and hyperhumid zone. The altitudinal series is Genisto hirsutaeCistetum ladaniferi, Cisto ladaniferi-Ulicetum argentei, Querco lusitanicae-Stauracanthetum boivinii, Erico australis-Cistetum populifolit to Cisto salvifolii-Ulicetum minoris. On syenite outcrops at mid-altitude, the altitudinal zonation starts with Halimio calycini and Ericetum australis-Rosmarinus community ined. and with Silene mellifera-Ranunculus bupleuroides community, goes on to Stauracantho-Drosophylletum and ends up with the Osyrio quadripartitae-Juniperetum turbinatae.

The altitudinal zonation of the original forests and the secondary heathland in the Spanish part of the study area is very similar to Portugal: Myrto-Quercetum suberis is followed by Teucrio-Quercetum suberis and RuscoQuercetum canariensis. The heathland communities are to some extent identical, to the other replaced by corresponding communities: Querco lusitanicaeStauracanthetum boivinii in the Monchique Mountains has the same matrix species like Genisto tridentis-Stauracanthetum quercetosum lusitanicae in the Aljibe Mountains. They differ by the AljibianTingitanian endemics Genista tridens, Satureja salzmanii, Klasea alcalae etc. and the Monchique endemics Centaurea crocata and C. fraylensis. Further details to the heathland communities of the Sierras of the Campo de Gibraltar can be taken from the abundant literature (Asensi \& Díez Garretas, 1987; Nieto Caldera et al., 1990; Pérez Latorre et al., 1993; Pérez Latorre et al., 1994; Nezadal et al., 1994; Deil, 1997a; Pérez Latorre et al., 1999). 


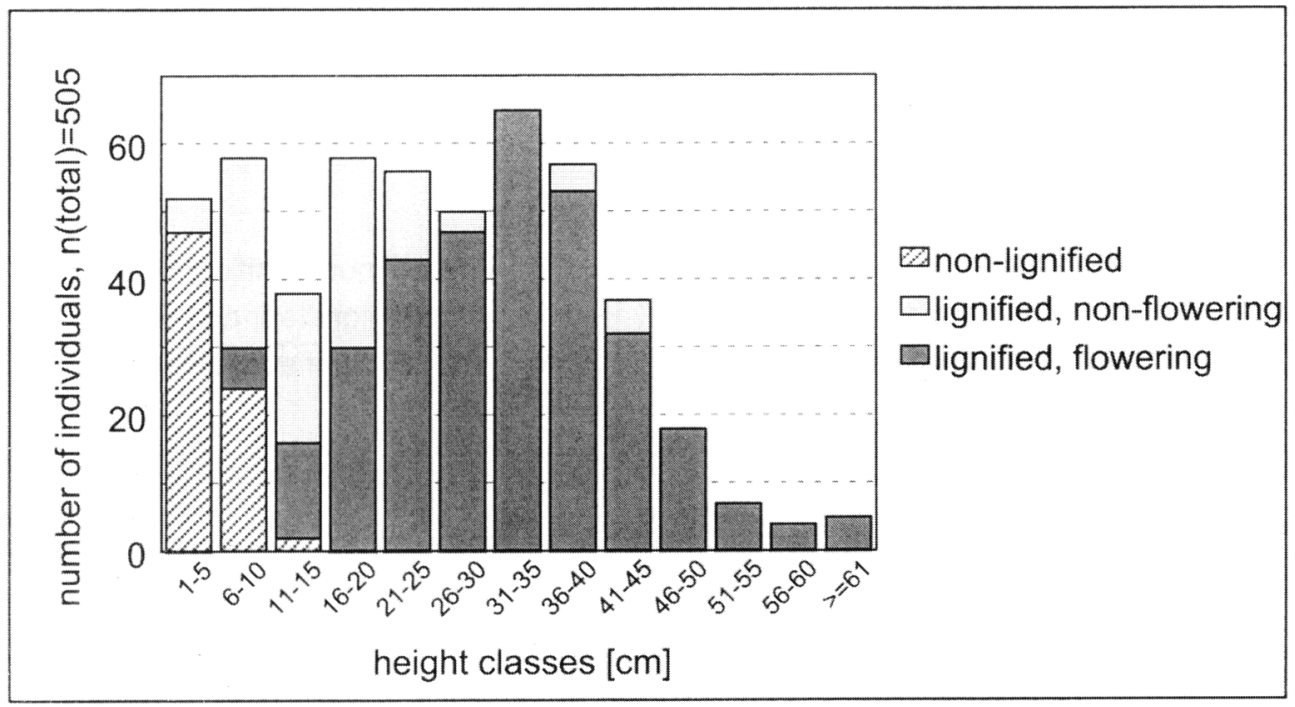

Figure 4. Height classes, lignification and flowering rate in Portuguese populations of Drosophyllum lusitanicum

\section{METHODS}

Field data were collected between April and July 1998. In the Serra de Monchique, the local distribution of Drosophyllum lusitanicum was mapped (fig. 2) and the number and size of all populations was documented. Additional data were collected in the Sierra del Aljibe and in other mountains of the Campo del Gibraltar. In total, 700 individuals in 19 different populations were measured. Table 1 shows the sample sizes per population and per study area. All studies have been restricted to nondestructive observations. Subterranean parts were not investigated; every shoot rooting independently was treated as an individual. Small sample sizes are due to a low number of individuals in the respective population.

To analyse the population structure of Drosophyllum, vegetative morphometric parameters, which can be interpreted as agestates or life-states (Barkham, 1980;
Holderegger, 1997), were measured. These parameters are plant height, rosette diameter and degree of lignification in the basal parts of the specimen. To get an insight into the generative reproduction strategy, the following data were noted: number of buds, flowers, fruits, seeds per fruit and seedling occurrence and establishment.

Phytosociological relevés were made in all kind of habitats (primary and secondary) where Drosophyllum lusitanicum occurred. To see whether Drosophyllum exhibits an apophytic character even impoverished stands at roadside verges and on fire-prevent strips were sampled. In the Serra de Monchique, structural transects of several meters length with exact position and size of Drosophyllum and its neighbouring specimens were taken to describe the spatial pattern in selected habitats. To study the sociological amplitude of Drosophyllum lusitanicum, the available data from the literature and our own new data are 


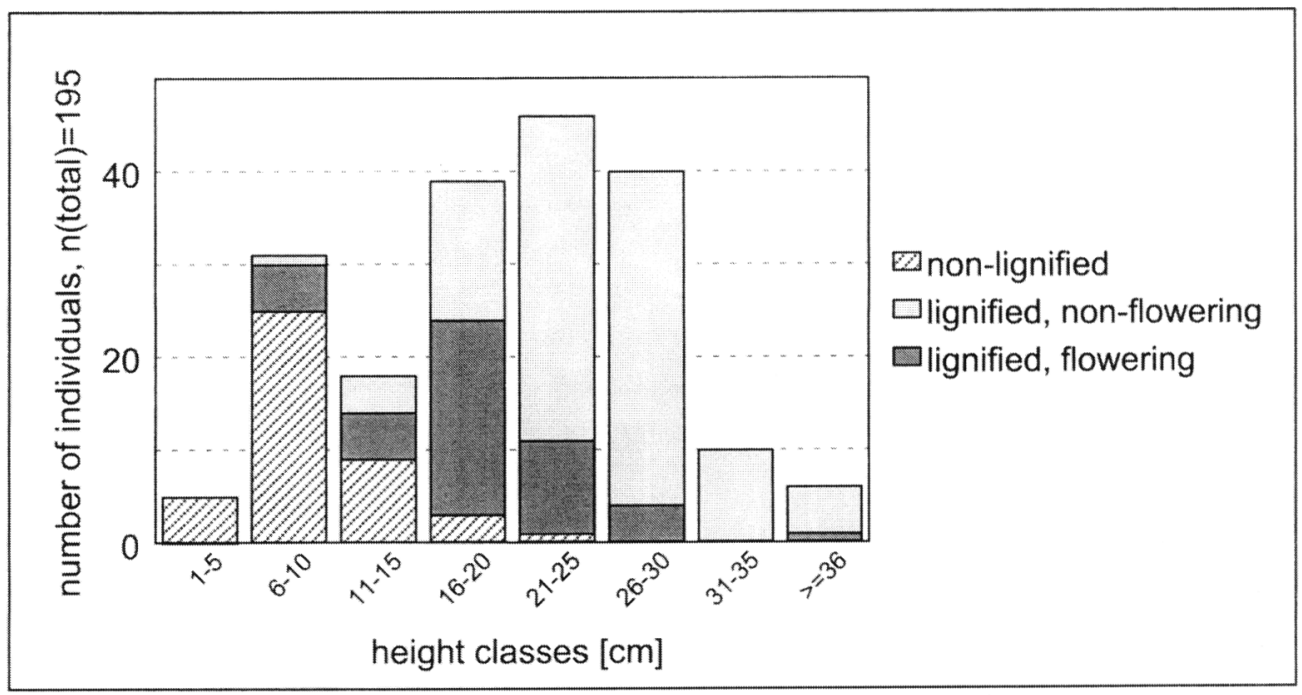

Figure 5. Height classes, lignification and flowering rate in Spanish populations of Drosophyllum lusitanicum

presented in a constancy table (tab. 3), which is reduced to the diagnostic and frequent species. The locations of the relevés are documented in figure 1. Classification and nomenclature of the plant communities are according to the Zurich-Montpellier school (Braun-Blanquet, 1964; Dierschke, 1994). Impoverished stands are typified following the concept of basal communities according to Kopecky \& Hejny (1974). Plant communities are typified and named according to RivasMartínez et al. (1990) in Portugal, and Deil (1997a) and Pérez Latorre et al. (1999) in Spain. In both countries nomenclature of plant species follows Valdés et al. (1987).

\section{RESULTS}

Local distribution and size of the populations: In the Serra de Monchique, 21 populations have been found (tab. 2). The altitudes of the localities range between $290 \mathrm{~m}$ and $560 \mathrm{~m}$ a.s.l., i.e. from the thermo- to the mesomediterranean bioclimatic level. A higher density of the populations can be stated in the leeward, southern and southeastern parts of the Serra (fig. 2). 10 populations occur on syenite, 11 on schists and greywakes. The average population size (statistical mean) is about 165 individuals. The most important population with about 800 specimens is near Chilrão. In the Sierras of the Campo de Gibraltar, the studied populations of Drosophyllum lusitanicum are all growing on Aljibe-sandstone. The biggest population with several thousands of individuals occurs near the summit of Picacho in the Sierra del Aljibe at an altitude of about $830 \mathrm{~m}$ a.s.l. in the mesomediterranean bioclimatic level.

Sociology and autecology of Drosophyllum lusitanicum: Drosophyllum lusitanicum has its highest frequency and abundance in very open Erica umbellataStauracanthus boivinii-heathlands on sandstone, syenite ridges and on steep loamy, 


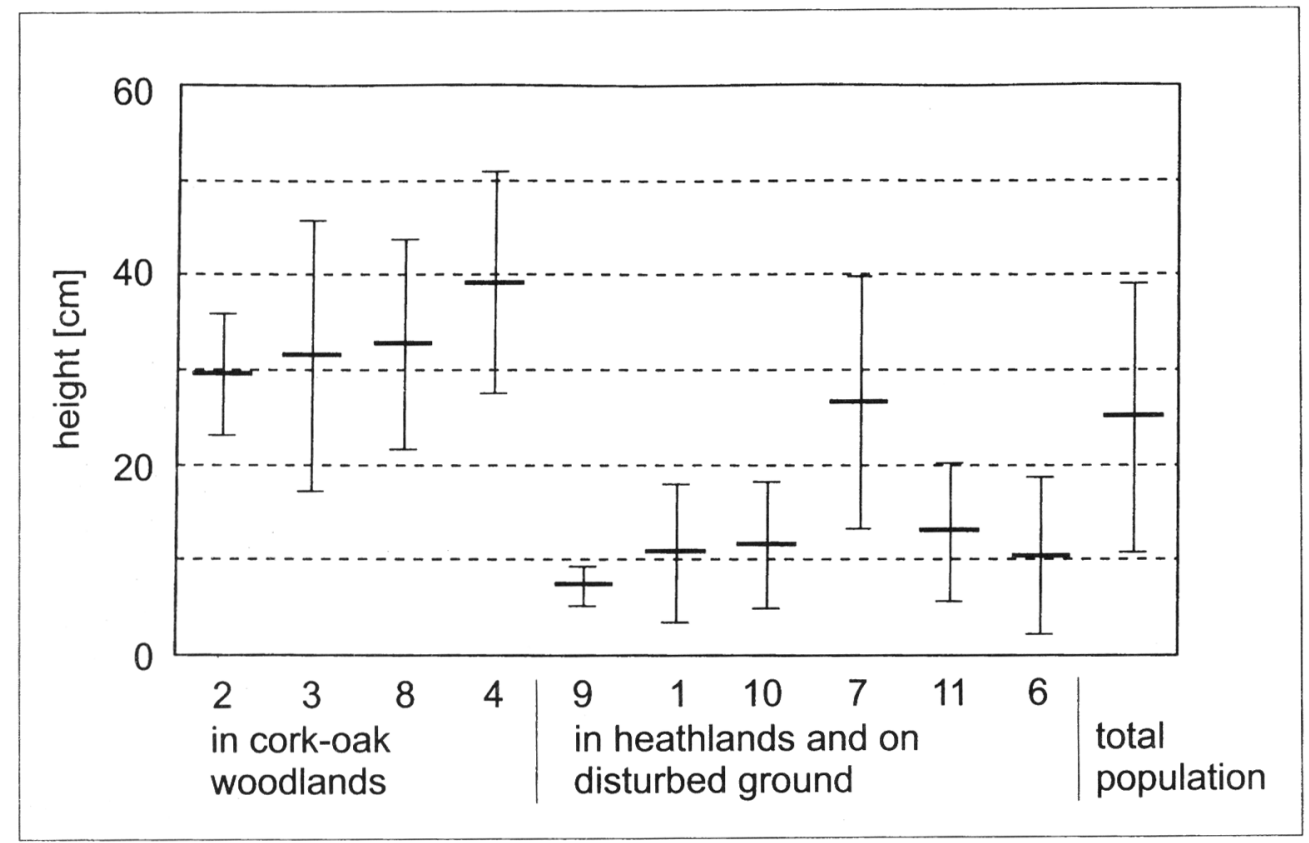

Figure 6. Mean height and height variability (standard deviation) of nine Drosophyllum populations in Portugal (numbers of populations like in table 1)

silty slopes on Aljibe-clay. This vegetation type was first described by Quézel et al. (1988) from the Tingitanian sector in northern Morocco as Stauracantho-Drosophylletum, based upon Drosophyllum lusitanicum as the only character species. In the type relevé, Cistus monspeliensis is very abundant, indicating the high fire frequency at this site in the Tangier area. The association also occurs in the Aljibian sector (Nezadal et al., 1994; Pérez Latorre et al., 1996; Deil, 1997a). Besides the typical subassociation (tab. 3, column 1), the subassociation saturejetosum salzmanii (tab. 3 , column 2) with a high frequency of Satureja salzmanii was stated for the Gaditanian Peninsula by Galán de Mera \& Vicente Orellana (1996).

If the fire frequency is lower and the relief moderate, surface runoff decreases and soils are deeper. At such sites, the Erica umbellata-heathlands have a dense vegetation canopy and Drosophyllum occurs in low frequency and with only some scattered individuals. These habitats can be enclosed in the Sierras of the Campo de Gibraltar into the Genisto tridentis-Stauracanthetum in its typical subassociation and into the subassociation with Quercus lusitanica on profound, podsolic soils (tab. 3, columns 3 and 4). In Morocco, the succession advances from the DrosophylloStauracanthetum to the Erica umbellata-Cistus crispus-community (Deil, 1997a). The investigated populations in the Campo de Gibraltar can be assigned to DrosophylloStauracanthetum and to Genisto tridentisStauracanthetum.

The community corresponding to the Genisto-Stauracanthetum in the Aljibian sector is the Querco lusitanicae-Stauracanthetum in the Monchiquense sector. The latter community 


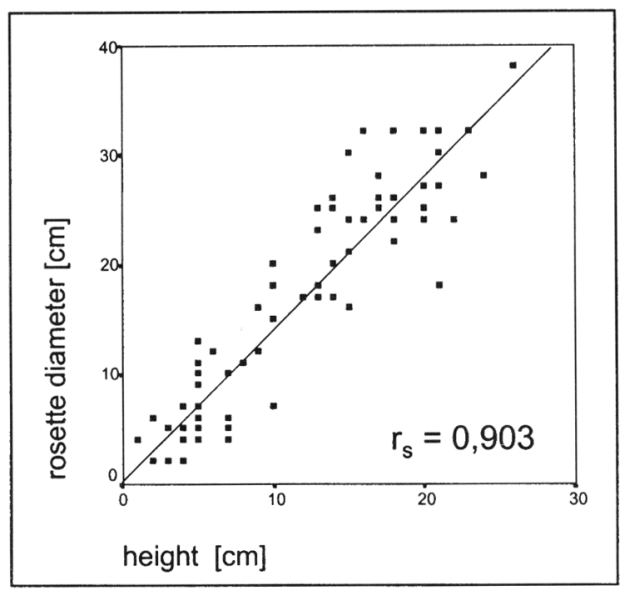

Figure 7. Correlation between rosette diameter and height in the population Mesquita in Portugal $(\mathrm{n}=$ 75 , Spearman's correlation coefficient $r_{s}$ )

is endemic in the Serra de Monchique. It is concentrated in the western and northwestern schistous parts of the Serra and occurs exclusively on wind exposed mountain ridges with stony soils with a shallow or even completely missing humus layer. From these sites, which seem to be original heath habitats, the heathlands have been expanded under human impact to Phillyreo-Arbutetum-climax sites and to originally open Quercus suberwoodland sites. Today, the traditional landuse (burning and pasturing) is abandoned and high growing shrubs are invading the secondary Erica umbellata-heathlands. Like in the closed Genisto-Stauracanthetum, Drosophyllum lusitanicum occurs in the dense and intact Querco-Stauracanthetum only with low frequency and very limited numbers of individuals (tab. 3, column 5).

In the Serra de Monchique, the former secondary heathlands have been transformed to a large extent into Eucalyptus-plantations within the last few decades (Malato Béliz, 1982; Krohmer \& Deil, 1999). In the ground layer of these forests, the floristic composition is very similar to the non-reforested sites. Character species of Querco-Stauracanthetum, like Centaurea crocata and $C$. fraylensis, are still occurring, but with lower frequency and abundance (tab. 3, column 6). The plant cover, however, is much more open, the sites are often terraced before planting. This vegetation type was called "matas artificiais" by Malato Béliz (1982). It is identical with type 10 (Eucalyptus afforestations in Quercus lusitanica heathland) in Seng \& Deil (1999). According to the nomenclature of Kopecky \& Hejny (1974), it can be named Drosophyllo[Stauracanthenion]-basal community. Drosophyllum lusitanicum has a good capability of recolonizing these terraced Eucalyptus-forests if the tree layer remains open and if vital populations of Drosophyllum are nearby. It can even expand to sites with high disturbance like roadside verges, timber storage areas and firebreak strips. The apophytic character of Drosophyllum is indicated by its higher frequency in disturbed (tab. 3, column 6) than in undisturbed (tab. 3, column 5) sites of the QuercoStauracanthetum.

Most of the 21 populations of Drosophyllum found in the Serra de Monchique occurred in the Querco-Stauracanthetum or in [Drosophyllo]-Stauracanthenion-basal communities. In higher altitudes and at northern slopes, Querco-Stauracanthetum respectively Genisto tridentis-Stauracanthetum is replaced by Erico australis-Cistetum populifolii. The Erica australis-heathland is taller and growing more densely than Erica umbellata-dominated heathland; Drosophyllum lusitanicum becomes less frequent (tab. 3, column 7). Populations with high numbers of individuals occur at disturbed sites (Eucalyptus- and Pinus pinasterplantations), where the plant canopy is open (fig. 3).

The occurrence of Drosophyllum lusitanicum in Ericion umbellataecommunities in Portugal outside the Serra de 


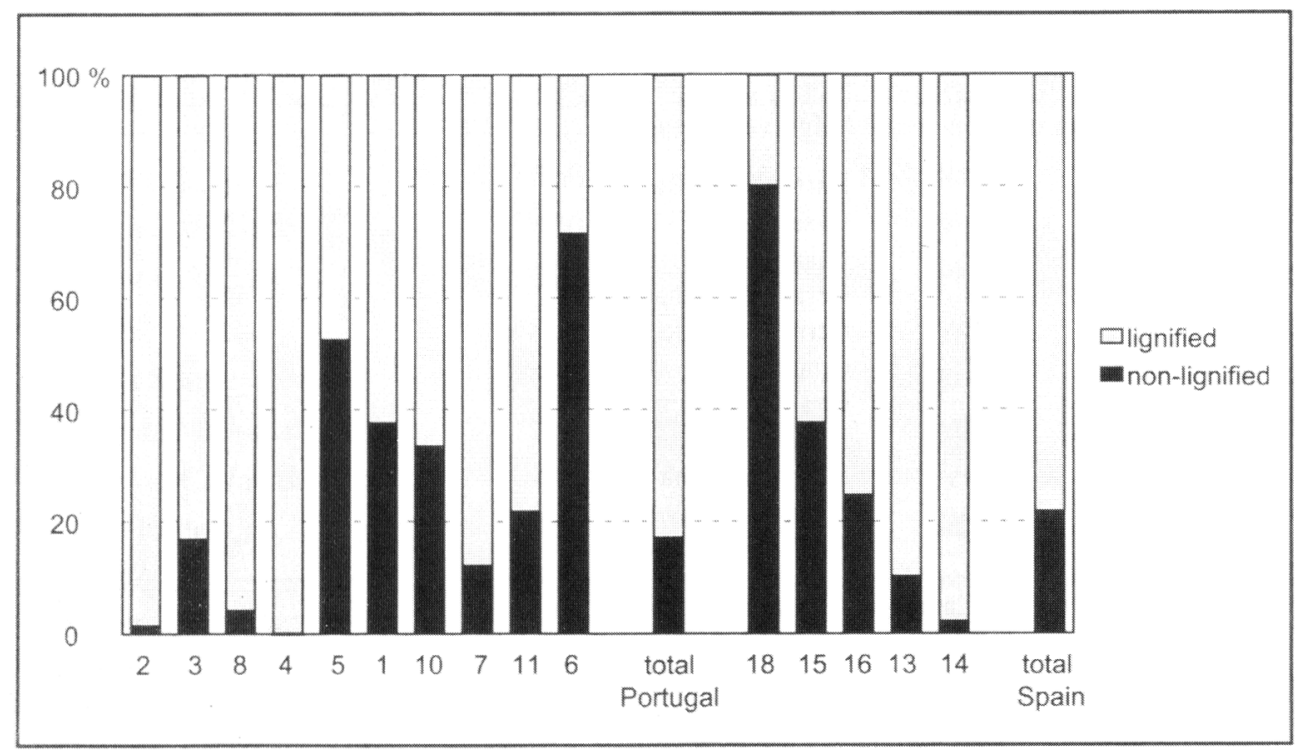

Figure 8. Lignification rate in different populations of Drosophyllum lusitanicum (for localities see table 1)

Monchique was documented by BraunBlanquet et al. (1964). In the heavily grazed Erico umbellatae-Ulicetum micranthi (tab. 3, column 10) as well as in the Ulici minorisEricetum umbellatae from the Serra de San Mamede (tab. 3, column 9) Drosophyllum lusitanicum appears with low frequency.

In cork-oak woodland, Drosophyllum lusitanicum remains restricted to the MyrtoQuercetum suberis (thermomediterranean subhumid bioclimate) (tab. 3 , column 8) where it prefers small disturbed areas, resulting from digging animals or from ploughing. Drosophyllum lusitanicum does not occur in closed thermo- and mesomediterranean humid cork-oak woodlands with dense litter (TeucrioQuercetum suberis in Spain respectively Sanguisorbo-Quercetum suberis in Portugal).

Population structure: Plant height, lignification rate and rosette diameter are parameters which can be easily measured in a non-destructive way and are indirect parameters of the age of the individuals. Figures 4 and 5 show the correlation between height classes, lignification in the basal parts and flowering rate in all measured specimen in Portugal respectively Spain. In Portugal (fig. 4, 505 individuals measured in total), the proportion of the non-lignified individuals decreases continuously in the first three height classes, whereas the proportion of flowering individuals increases in the same way. $>6 \mathrm{~cm}$ is the minimum size for flowering, individuals $>$ $25 \mathrm{~cm}$ are nearly all flowering. A maximum height of $72 \mathrm{~cm}$ was stated in Portugal. All flowering specimen are lignified in the basal parts of the shoots. The Spanish populations (fig. 5, 195 individuals measured in total) show similar tendencies. $>5 \mathrm{~cm}$ is the minimum size for flowering, all flowering individuals are lignified. In contrast to the Portuguese populations, the specimen are dwarfishly growing $(>40 \mathrm{~cm})$ and the rate of flowering is during flowering peak much lower.

To see how the density of the plant canopy and the co-occurring species affect the vitality 


\begin{tabular}{clc}
\hline population & \multicolumn{1}{c}{ localities } & \multicolumn{1}{c}{$\begin{array}{c}\text { number of } \\
\text { sampled individuals }\end{array}$} \\
\hline Study area Serra de Monchique (Algarve, Portugal) & 16 \\
1 & Barranco do Bufo & 75 \\
2 & Casais & 30 \\
3 & Casais South & 75 \\
4 & Cerro da Malhada Velha & 42 \\
5 & Cerro Redondo & 7 \\
6 & Cimalhas & 75 \\
7 & Eira do Bufo & 75 \\
8 & Fornalha & 3 \\
9 & Malhada Velha 2 & 75 \\
10 & Mesquita & 74 \\
11 & Padescas & \\
\hline
\end{tabular}

Study area Sierras del Campo de Gibraltar (Cádiz, Spain)

\begin{tabular}{llc}
12 & Cerro de las Callejuelas & 5 \\
13 & El Picacho 1 & 50 \\
14 & El Picacho 2 & 50 \\
15 & Puerto de Gáliz 1 & 16 \\
16 & Puerto de Gáliz 3 & 49 \\
17 & Sierra de Ojen 1 & 2 \\
18 & Sierra de Ojen 2 & 20 \\
19 & Sierra del Niño & 3 \\
\hline
\end{tabular}

Table 1: Location of the studied populations and number of sampled individuals of Drosophyllum lusitanicum

and the competitiveness of Drosophyllum, populations in different communities have been studied. fig. 6 shows the mean height and height variability of nine populations in Portugal (no data available from Spain). The average height (statistical mean) is about $25 \mathrm{~cm}$, individuals in opened cork-oak woodlands (populations 2, 3, 4 and 8 ) and tall-growing heathland (population 7) being significantly taller than those in lowgrowing heathland and in open areas. Height class distribution is different: in open areas low classes predominate, populations in corkoak woodlands have a balanced distribution, tall specimens dominate in heathlands of the Erico australis-Cistetum populifolii.

The parameter rosette diameter confirms these results. The mean rosette diameter for all measured individuals is about $21 \mathrm{~cm}$. There are no significant differences between all
Portuguese and all Spanish populations and between the different Spanish populations $(\mathrm{p}=$ 0,165, Kruskal-Wallis H-test, (Sachs 1993)). A comparison of the Portuguese populations, however, shows significant differences between the studied populations (tab. 4). Individuals in the cork-oak woodlands and tallgrowing heathland have significantly larger rosette diameters (about $30 \mathrm{~cm}$ ) than those in low-growing heathland and open habitats (about 23cm, p < 0,001, Mann-Whitney U-test, Sachs 1993). The measured parameters plant height and rosette diameter are significantly correlated to each other in almost all populations in Portugal and Spain (tab. 5). A correlation diagram of the population 10 "Mesquita" is shown as an example (fig. 7).

Clearer than plant height or rosette diameter, lignification of the basal shoot can 


\begin{tabular}{|c|c|c|c|c|c|}
\hline & population / locality & $\begin{array}{l}\text { altitude } \\
\text { m a.s.l. }\end{array}$ & aspect & substrate & $\begin{array}{c}\text { number of } \\
\text { individuals }\end{array}$ \\
\hline \multirow{21}{*}{ 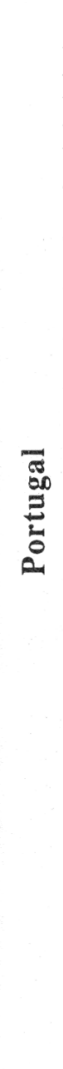 } & Aldobreira & 250 & NE, E & schist & 450 \\
\hline & Barranco do Bufo & 450 & $\mathrm{~S}$ & syenite & 50 \\
\hline & Barreiras Ruivas & 325 & $\mathrm{E}$ & syenite & 85 \\
\hline & Casais & 420 & $\mathrm{~S}, \mathrm{SW}$ & syenite & 265 \\
\hline & Casais South & 385 & SSE & syenite & 32 \\
\hline & Cerro da Malhada Velha & 560 & SE & syenite & 80 \\
\hline & Cerro do Covao da Loba & 415 & SE & schist & 121 \\
\hline & Cerro Redondo & 460 & $\mathrm{~S}$ & schist & 42 \\
\hline & Chilrão & 460 & NE, E & schist & 800 \\
\hline & Cimalhas & 430 & NW & schist & 7 \\
\hline & Eira do Bufo & 390 & SE & syenite & 450 \\
\hline & Estebeiras & 330 & SE & schist & 1 \\
\hline & Fonte Santa & 270 & NE & schist & 87 \\
\hline & Fornalha & 290 & SE & syenite & 95 \\
\hline & Malhada Velha 2 & 515 & SW & syenite & 3 \\
\hline & Mesquita & 490 & $\mathrm{~S}, \mathrm{E}$ & schist & 165 \\
\hline & Morgado & 415 & $\mathrm{~S}$ & syenite & 205 \\
\hline & Padescas & 335 & S, SSE & schist & 80 \\
\hline & Picota & 400 & SSW & syenite & 20 \\
\hline & Taipas & 340 & SE & schist & 44 \\
\hline & Zevinho & 440 & NE, SE & schist & 385 \\
\hline & Cerro de las Callejuelas 4 & 590 & SW & Alljibe-sandstone & 117 \\
\hline & Cerro de las Callejuelas 5 & 570 & SW & Alljibe-sandstone & 8 \\
\hline & Cerro de las Callejuelas 6 & 550 & $\mathrm{~S}$ & Alljibe-sandstone & 2 \\
\hline & Cerro de las Callejuelas 7 & 540 & SE & Alljibe-sandstone & 45 \\
\hline & El Picacho 1 & 690 & SE & Alljibe-sandstone & 187 \\
\hline & El Picacho 2 & $770-830$ & SE & Alljibe-sandstone & 8000 \\
\hline & Puerto de Gáliz 1 & 420 & SW & Alljibe-sandstone & 16 \\
\hline & Puerto de Gáliz 2 & 470 & NW & Alljibe-sandstone & 24 \\
\hline & Puerto de Gáliz 3 & 610 & $\mathrm{~S}$ & Alljibe-sandstone & 91 \\
\hline & Sierra de Ojén 1 & 450 & $S$ & Alljibe-sandstone & 2 \\
\hline & Sierra de Ojén 2 & 450 & SE & Alljibe-sandstone & 51 \\
\hline & Sierra del Niño & 240 & SE & Alljibe-sandstone & 3 \\
\hline
\end{tabular}

Table 2. Environment and size of the studied populations of Drosophyllum lusitanicum 


\begin{tabular}{|c|c|c|c|c|c|c|c|c|c|c|}
\hline Column & 1 & 2 & 3 & 4 & 5 & 6 & 7 & 8 & 9 & 10 \\
\hline Number of relevés & 14 & 5 & 32 & 26 & 32 & 10 & 23 & 35 & 15 & 21 \\
\hline \multicolumn{11}{|c|}{ Stauracantho-Drosophylletum lusitanici CS } \\
\hline Drosophyllum lusitanicum & V & V & I & II & I & III & I & I & I & I \\
\hline \multicolumn{11}{|c|}{ Stauracantho-Drosophylletum saturejetosum DS } \\
\hline Satureja salzmanii & I & $\mathrm{V}$ & II & III & . & . & . & . & . & . \\
\hline \multicolumn{11}{|c|}{ Genisto tridentis-Stauracanthetum boivinii CS } \\
\hline Genista tridens & III & . & IV & $\mathrm{V}$ & . & . & . & . & . & . \\
\hline Klasea alcalae & III & II & III & IV & . & . & . & . & . & \\
\hline Bupleurum foliosum & I & I & I & I & . & & . & . & . & . \\
\hline \multicolumn{11}{|c|}{ Querco lusitanicae-Stauracanthetum boivinii CS } \\
\hline Lavandula stoechas ssp. luisieri & . & . & . & . & IV & . & III & I & II & . \\
\hline Centaurea crocata & . & . & . & . & III & III & II & I & . & . \\
\hline Centaurea fraylensis & . & . & . & . & II & IV & . & . & . & . \\
\hline Klasea monardii & . & . & . & . & II & I & . & I & . & . \\
\hline Lavandula viridis & . & . & . & . & I & . & I & I & . & . \\
\hline \multicolumn{11}{|l|}{ Stauracanthenion boivinii DS } \\
\hline Stauracanthus boivinii & V & $\mathrm{V}$ & $\mathrm{V}$ & $\mathrm{V}$ & V & IV & I & . & . & . \\
\hline $\begin{array}{l}\text { Avenula sulcata s.l. } \\
\text { Ulici minoris-Ericetum umbellatae Cs }\end{array}$ & III & II & III & III & IV & IV & II & I & I & I \\
\hline $\begin{array}{l}\text { Ulici minoris-Ericetum umbellatae Cs } \\
\text { Ulex minor }\end{array}$ & . & . & . & & . & . & I & I & II & I \\
\hline \multicolumn{11}{|l|}{ Erico umbellatae-Ulicetum micranthi CS } \\
\hline Ulex micranthus & . & . & . & . & . & . & . & . & . & $\mathrm{V}$ \\
\hline \multicolumn{11}{|l|}{ Ericion umbellatae CS } \\
\hline Erica umbellata & II & IV & III & III & V & II & I & . & $\mathrm{V}$ & $\mathrm{V}$ \\
\hline Genista triacanthos & II & II & II & I & III & $\mathrm{I}$ & III & I & III & III \\
\hline Genista tridentata & II & . & III & II & V & $\mathrm{V}$ & II & I & $\mathrm{V}$ & IV \\
\hline Erica australis & II & . & II & IV & IV & III & $\mathrm{V}$ & I & II & I \\
\hline Halimium alyssoides ssp. lasianthum & II & I & I & IV & I & . & . & . & IV & II \\
\hline Thymus villosus & III & I & IV & II & II & I & . & . & & \\
\hline Polygala microphylla & I & I & II & II & . & . & . & . & I & I \\
\hline Quercus lusitanica & II & . & II & $\mathrm{V}$ & V & IV & II & . & . & . \\
\hline Halimium ocymoides & . & . & . & . & IV & III & I & . & III & I \\
\hline Ornithogalum broteroi & . & . & . & . & IV & II & I & I & II & . \\
\hline Erica cinerea & . & . & . & & . & . & . & . & IV & IV \\
\hline \multicolumn{11}{|l|}{ Calluno-Ulicetea CS } \\
\hline Calluna vulgaris & III & III & IV & $\mathrm{V}$ & $\mathrm{V}$ & $\mathrm{V}$ & IV & I & IV & V \\
\hline Agrostis curtisii & II & I & IV & IV & IV & III & I & & V & $\mathrm{V}$ \\
\hline Simethis planifolia & II & . & I & I & II & II & I & I & IV & IV \\
\hline Erica scoparia & III & I & IV & IV & II & II & I & I & . & . \\
\hline \multicolumn{11}{|l|}{ Cisto-Lavanduletea, Lavanduletalia CS } \\
\hline Tuberaria lignosa & III & III & III & III & III & IV & II & I & I & I \\
\hline Cistus salvifolius & II & I & IV & III & III & II & $\mathrm{V}$ & III & . & . \\
\hline Cistus crispus & III & I & II & $\mathrm{I}$ & I & . & II & I & . & . \\
\hline Lavandula stoechas & IV & I & IV & III & I & II & I & II & . & . \\
\hline Halimium halimifolium & III & . & II & I & I & . & . & I & . & . \\
\hline Cistus populifolius ssp. major & . & I & I & III & II & I & III & I & . & . \\
\hline Cistus ladanifer & . & . & I & II & V & IV & V & I & . & . \\
\hline Helichrysum stoechas & . & . & . & . & III & II & I & I & . & . \\
\hline
\end{tabular}




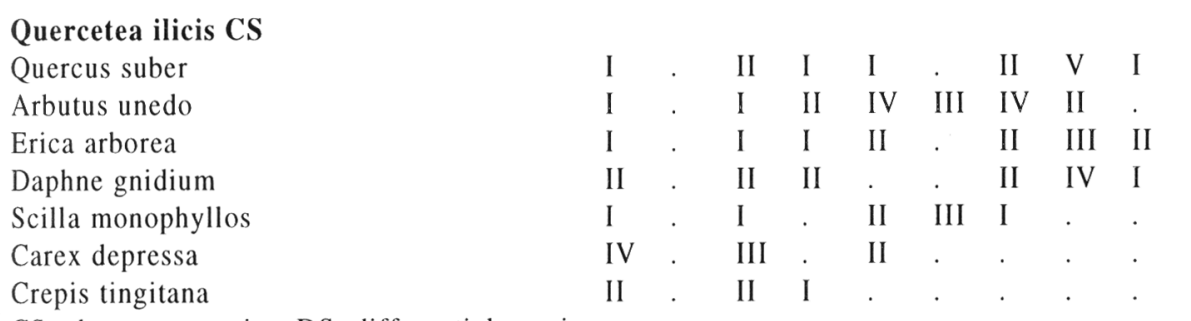

CS: character species, DS: differential species

1: Stauracantho boivinii-Drosophylletum (Quezel et al., 1988 Morocco; Deil, 1997a Spain and Morocco);

2: Stauracantho-Drosophylletum saturejetosum salzmanii (Galán de Mera \& Vicente Orellana, 1996 Spain); 3: Genisto tridentis-Stauracanthetum (Rivas-Martínez, 1979 Spain; Galán de Mera \& Vicente Orellana 1996 Spain; Deil, 1997a Spain and Morocco and own material); 4: Genisto tridentis-Stauracanthetum quercetosum lusitanicae (Pérez Latorre et al., 1993 Spain; Galán de Mera \& Vicente Orellana, 1996 Spain and own material); 5 : Querco lusitanicae-Stauracanthetum (Malato Béliz, 1982 Portugal; Galán de Mera \& Vicente Orellana 1996 Spain; Deil et al., in prep. Portugal and own material); 6: [Drosophyllo]Stauracanthenion basal community (own material) 7: Erico australis-Cistetum populifolii (Braun-Blanquet et al., 1964 Portugal; Malato Béliz, 1982 Portugal; Pérez Latorre et al. 1993 Spain; Deil et al., in prep. Portugal and own material); 8: Myrto-Quercetum suberis (Rivas-Martínez et al., 1990 Portugal; Nieto Caldera et al., 1990 Spain; Pérez Latorre et al., 1993 Spain and own material); 9: Ulici minoris-Ericetum umbellatae (Braun-Blanquet et al., 1964 Portugal); 10: Erico umbellatae-Ulicetum micranthi (BraunBlanquet et al., 1964 Portugal)

Table 3. Sociology of Drosophyllum lusitanicum in the South-western Iberian Peninsula and in Northwest Morocco (constancy table, reduced to frequent and diagnostic species)

be used as a differentiating character of adult versus juvenile plants. On average, the proportion of juvenile plants is about $20 \%$ in Portuguese as well as in Spanish populations (fig. 8). We can however state an enormous variability of the rate of juveniles from one population to the other. Some populations in Portuguese cork-oak forests are nearly without any juvenile plants (populations 2 and 8). They must be interpreted as over-aged. Population 4 is too small to be significant. A very low rate of non-lignified specimens was further stated in the mass population (> 8000 individuals) near Picacho summit in Spain. This population has re-established itself after a fire event. It has a strong cohort structure and nearly the whole cohort is already in the lignified stage. Since this event, new seedling establishment seems to be extremely rare.

In both study areas, Drosophyllum lusitanicum flowers from April to July. Most of the rosettes develop one, seldom two, flowering shoots. The flowering rate ranges between 13 and $96 \%$, depending on the habitat and the age, as determined by the size-structure (height, rosette diameter, lignification) of the population (fig. 4 and 5). With increasing plant size, the flowering rate increases (tab. 5). In the cork-oak woodlands and in the tall-growing Erica australis-heathlands, the flowering rate was constant during the observation period from April to June, in open Erica umbellataheathland it increased with a flowering peak end of June.

Ortega Olivencia et al. (1995) stated that seed number per fruit is quite a constant parameter throughout the populations in Spain. We counted 3839 seeds (397 fruits) in Portuguese and 1155 seeds (81 fruits) in Spanish populations and can confirm the 


\begin{tabular}{cccccccccc}
\hline & 2 & 3 & 8 & 4 & 9 & 1 & 10 & 7 & 11 \\
\hline 3 & $\mathrm{~ns}$ & & & & & & & & \\
8 & $* *$ & $\mathrm{~ns}$ & & & & & & & \\
4 & $* * *$ & $*$ & $* *$ & & & & & & \\
9 & $* * *$ & $*$ & $* * *$ & $* * *$ & & & & & \\
1 & $* * *$ & $* * *$ & $* * *$ & $* * *$ & $\mathrm{~ns}$ & & & & \\
10 & $* * *$ & $* * *$ & $* * *$ & $* * *$ & $\mathrm{~ns}$ & $\mathrm{~ns}$ & & & \\
7 & $\mathrm{~ns}$ & $\mathrm{~ns}$ & $* *$ & $* * *$ & $* *$ & $* * *$ & $* * *$ & & \\
11 & $* * *$ & $* * *$ & $* * *$ & $* * *$ & $\mathrm{~ns}$ & $\mathrm{~ns}$ & $\mathrm{~ns}$ & $* * *$ & \\
6 & $* * *$ & $* * *$ & $\mathrm{~ns}$ & $* * *$ & $\mathrm{~ns}$ & $\mathrm{~ns}$ & $\mathrm{~ns}$ & $* *$ & $\mathrm{~ns}$ \\
\hline
\end{tabular}

$\mathrm{ns}=$ not significant, $*=\mathrm{p}<0,05, * *=\mathrm{p}<0,01, * * *=\mathrm{p}<0,001($ Mann-Whitney-U-

test)

Table 4. Significance test of the parameter "rosette diameter" related to populations in Portugal.

constant number within the populations of both study areas. There is however a significant difference ( $\mathrm{p}<0,001$, Mann-Whitney U-test) between both study areas with about 10 seeds per fruit in Portugal and 14 in Spain. Because of its constancy, seed number per fruit is not a suitable character to measure vitality.

The observations about seedling density and seedling patterns are very preliminary; data about seedling survival rates in the field are still missing. Most of the seedlings have been observed on open sites with shallow soils and without any litter. Within those habitats, seedlings are mostly established in the shadow of dwarf shrubs, which seem to offer safe sites for seedling survival. In cork-oak woodlands, seedlings are very rare and appear only in places where the humus layer is disturbed by animal activity or by ploughing.

The generative strategy of Drosophyllum lusitanicum is supported by vegetative sprouting. In Quercus suber-forests we observed a few specimens with long superficial creeping shoots (up to $40 \mathrm{~cm}$ ). These shoots are able to develop adventitious roots and daughter rosettes.

\section{DISCUSSION AND CONCLUSIONS}

Drosophyllum lusitanicum occurs in several acidophilous heathland communities in the southwestern part of the Iberian Peninsula and in northwestern Morocco. The species is most frequent in low growing and open heathland and can - in accordance with RivasMartínez (1979) - in a broader sense be evaluated as a character species of Ericion umbellatae. The highest densities and the most numerous populations occur in the Drosophyllo-Stauracanthetum where this heathland is original: wind exposed mountain ridges in the mesomediterranean belt and stony/ loamy slopes in the thermo- and mesomediterranean belts. In both situations, periodical fire is an intrinsic factor of the ecosystem. The community can expand to less shallow soils, favoured by a higher, man-made fire-frequency and by clearing of the forests.

Beside Drosophyllum lusitanicum, other heliophilous dwarf shrubs, which are endemic in the southwestern Mediterranean and must have evolved in an open heathland of Ericion umbellatae-type, are Nothobartsia aspera (Galán de Mera et al., 1996) and Teucrium salviastrum ssp. rubriflorum (Deil, 1997b). These dwarf shrubs can also exist under a very open Quercus suber tree layer. In the Sierras del Campo de Gibraltar, sometimes native Pinus pinaster populations grow within this vegetation (Pérez Latorre et al., 1999). Drosophyllum occurs with low frequency and low individual numbers in open cork-oak forests on shallow rocky soil in the 
thermomediterranean bioclimate (MyrtoQuercetum suberis). This is not obvious in so far as Pérez Latorre et al. (1993) placed the Stauracantho-Drosophylletum in the TeucrioQuerceto suberis S. series. Nieto et al. (1990) did not mention Drosophyllum lusitanicum in Spanish Myrto-Quercetum suberiscommunities.

Drosophyllum lusitanicum can be considered as a potentially endangered species. It occurs in isolated populations and often in small individual numbers. In Spain, most of the populations are situated within the Natural Park "Los Alcornocales" and their protection status is sufficient. In the Serra de Monchique, there exists not a single nature reserve at the moment. Apart from the extremely rare Rhododendron-ravines, the most interesting places in the Serra from the botanical point of view are some mountain ridges in the schistous part of the Serra with Querco-Stauracanthetum and its endemics Centaurea crocata and $C$. fraylensis and some rocky outcrops in the central syenite area. In the latter sites, Drosophyllum occurs in a vegetation complex with some other communities like Halimio calycini-Ericetum australis rosmarinetosum ined., Sileno melliferae-Ranunculetum bupleuroidis ined., Osyrio quadripartitaeJuniperetum turbinatae, Laurentio-Juncetum, Isoeto histricis-Radioletum linoidis, Loto subbiflori-Chaetopogonetum fasciculati, Arenaria conimbricensis-Sedum andegavensecommunity etc. (Rudner et al., 1999). These sites should be protected from Eucalyptusplantations, changes to the hydrological system and from the direct destruction by syenite exploitation.

Open soil seems to facilitate the establishment and the regeneration of Drosophyllum. Opening of the plant canopy can either occur by human or animal activities or be induced by natural disturbance (erosion, fire). The species has a certain pioneer character. It can recolonize burned sites, terraced slopes and disturbed roadsides. Its strategy reacting to disturbance is that of a reseeder (Ojeda et al., 1996b). This is supported by the fact that autogamy is prevailing (Ortega Olivencia et al., 1995). Autogamy is widespread in species with a pioneer character at extreme habitats.

The current land-use trends can affect the populations in different and contradicting ways. A diminishing anthropo-zoogenic disturbance in oak forests will reduce the germination niches, but favour the life span and the vegetative regeneration. The abandonment of the traditional pasture use and the burning management of secondary Ericion umbellataeheathland in Spain and Portugal will allow the regrowth of dense Erica australis-heathland and of the tall-growing Phillyreo-Arbutetum and Cytiso-Arbutetum-Maquis. This will reduce the area of the Drosophyllo-Stauracanthetum to its original sites. The effect of land-use in Morocco is opposite of that in Portugal and Spain. In Morocco, the populations of endemic Ericion umbellatae-heathland taxa are threatened by a very high fire frequency and by an ongoing rotating cultivation even on steep slopes.

To define age-states, Holderegger (1997) recommends using only vegetative parameters. The vegetative parameters "plant height" and "rosette diameter" are almost always significantly correlated with each other. They permit a description of the population structure and can be interpreted as age-states or lifestates (Barkham, 1980; Holderegger, 1997). In most species, reproductive capability, growth and survival probability are strongly correlated with their size respective their age-states (Werner \& Caswell, 1977; Silvertown et al., 1993). The older an individual is, the more rosettes, flowers and seeds does it produce. Big individuals should be older and will have a higher reproductive capability. When low sizes dominate, the populations can be interpreted as young. This is the case for 


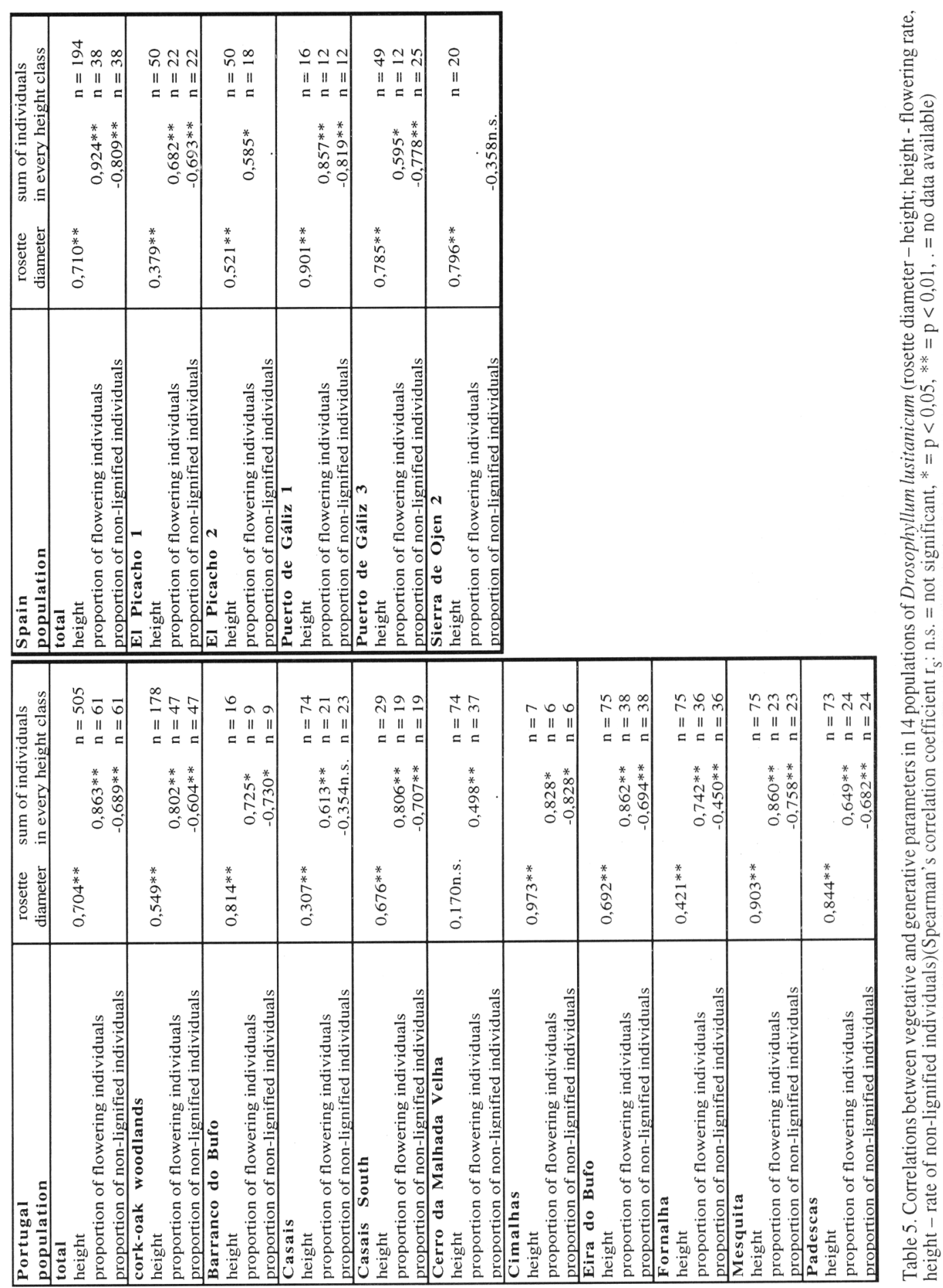


Drosophyllum lusitanicum populations in open habitats. This interpretation is supported by the flowering behaviour which is significantly correlated with height and lignification. In a further research study it would be an interesting question whether the differences between Portuguese and Spanish populations, for example the different seed numbers per fruit, are phenotypic modifications or are based upon a genetic separation. In a gardening experiment, the correlation between age, lignification, basal shoot diameter, plant height and rosette diameter should be investigated in a planted population to get better data about the age structure of the field populations.

Following the age-state-concept, the populations in Myrto-Quercetum and in Erico australis-Cistetum populifolii are over-aged. A further reason for the occurrence of large and rich flowering plants in cork-oak woodland could be the better nutritional situation at those sites. Seedling survival should be better than in open heathlands because nutrient supply from the soil or from prey capture favour germination and seedling survival (Garrido Díaz \& Ortiz Herrera, 1996). Seed rain should be sufficient in cork-oak forest populations of Drosophyllum but hard data are still missing. The insufficient regeneration might be due to the rarity of germination niches. The continuous litter and the undisturbed soil might be responsible for the over-aging of those populations. The low generative regeneration in Quercus suber-forests is, to some extent, compensated by vegetative regeneration. Further studies should include investigations about germination and seedling establishment under field conditions. Especially, the influence of chamaephytes and litter for the germination should be a topic in further research.

For the moment it is unknown to what extent Drosophyllum lusitanicum is able to tolerate or recover from heavy disturbances like terracing for Eucalyptus-plantations or after forest harvesting. Drosophyllum is nautochoric and its seeds can be transported by runoff. Exact data about other dispersal agents (ants ?), the dispersal efficiency and distance are missing. We also do not know whether it performs a transient or permanent seed bank.

\section{SYNTAXONOMICAL CONSPECTUS}

QUERCETEA ILICIS Br.-Bl. ex A. \& O. Bolòs 1950 + Quercetalia ilicis Br.-Bl. ex Molinier 1934 em. Rivas-Martínez 1975

* Querco rotundifoliae-Oleion sylvestris Barbero, Quézel \& Rivas-Martínez in Rivas-Martínez, Costa \& Izco 1986

Teucrio baetici-Quercetum suberis Rivas-Martínez ex Díez Garretas, Cuenca \& Asensi 1988 [dense cork-oak woodland, in subhumid, humid and hyperhumid climate, mainly on sandy soils, typical for the Aljíbico sector]

Myrto communis-Quercetum suberis Barbéro, Quézel \& Rivas-Martínez 1981 [silicicolous corkoak woodland with south-west Ibero-Atlantic distribution, thermomediterranean, subhumidhumid bioclimate]

Rusco hypophylli-Quercetum canariensis RivasMartínez 1975 [silicicolous cork-oak woodland, thermo- and mesomediterranean, humid and hyperhumid bioclimate, Aljíbico sector]

* Quercion broteroi Br.-B1., Pinto da Silva \& Rozeira 1956 em. Rivas-Martínez 1975 corr. V. Fuente 1986 Sanguisorbo hybridae-Quercetum suberis Rivas Goday 1959 em. Rivas-Martínez 1975

typicum [mesomediterranean cork-oak woodland, subhumid-humid bioclimate, westIberian distribution]

quercetosum canariensis Rivas-Martínez, Lousa, Díaz, Fernández González \& Costa 1990 [mesomediterranean cork-oak woodland with Quercus canariensis]

+ Pistacio lentisci-Rhamnetalia alaterni RivasMartínez 1975

* Juniperion turbinatae Rivas-Martínez 1975 corr. 1987 Osyrio quadripartitae-Juniperetum turbinatae (Rivas-Martínez 1975) Rivas-Martínez, Lousa, Díaz, Fernández-Gonzáles \& Costa 1990 [thermomediterranean shrubland in coastal areas of the Gaditano-Onubo-Monchiquense-Sadense sectors]

* Ericion arboreae Rivas-Martínez (1975) 1987

Phillyreo angustifoliae-Arbutetum unedonis Rivas Goday \& F. Galiano in Rivas Goday \& cols. 1959 [thermo-mesomediterranean Arbutus unedo-shrub in the south-western Iberian Peninsula] 
Cytiso baetici-Arbutetum unedonis Nieto Caldera, Pérez Latorre \& Cabezudo 1990 [thermomesomediterranean Arbutus unedo-Cytisus-Genista shrub in the Algibian sector]

CALLUNO-ULICETEA Br.-B1. \& R. Tx. ex Klika \& Hadac 1944

+ Calluno-Ulicetalia (Quantin 1935) R. Tx. 1937 em. Rivas-Martínez 1979

* Ericion umbellatae Br.-Bl., Pinto da Silva, Rozeira \& Fontes $1952 \mathrm{ampl}$. Rivas-Martínez 1979

- Ericenion umbellatae Rivas-Martínez 1979

Cisto salvifolii-Ulicetum minoris $\mathrm{Br}$.- $\mathrm{Bl}$., Pinto da Silva, Rozeira 1964 [endemic heathland in Portugal (Bajo Alentejano-Monchiquense subsector), humid to hyperhumid bioclimate]

- Stauracanthenion boivinii Rivas-Martínez 1979

Querco lusitanicae-Stauracanthetum boivinii Rothmaler 1954 ex Malato Beliz 1982 [low-growing heathland only on schists, degradation community of the Myrto communis-Quercetum suberis, endemic in Portugal, humid and hyperhumid bioclimate]

Genisto tridentis-Stauracanthetum boivinii RivasMartínez 1979

typicum [silicicolous, low-growing heathland in the Aljíbico sector]

quercetosum lusitanicae Pérez Latorre, Nieto Caldera \& Cabezudo 1993 [subassociation with high frequency of Quercus lusitanica on deeper soils]

Stauracantho boivinii-Drosophylletum lusitanici Quézel, Barbero, Benabid, Loisel \& Rivas-Martínez 1988 [open, low-growing, silicicolous scrub on sandy soils, Aljíbico and Tangerino sector]

saturejetosum salzmanii Galán de Mera \& Vicente Orellana 1996 [differs by the high frequency of Satureja salzmanii, Aljíbico sector]

Drosophyllo-[Stauracanthenion]-basal community [floristically impoverished Stauracanthenion-community on habitats which are heavily disturbed by man, mainly in the Monchiquense sector]

Erica umbellata-Cistus crispus-community Deil 1997 [fire-promoted heathland community in the Tangerino sector]

Halimium calycinum-Erica australis-Rosmarinus community [dwarf heathland on syenit outcrops in the Monchiquense sector, mesomediterranean, subhumid bioclimate, transitional association between the Ericion umbellatae and the UliciCistion]

Silene mellifera-Ranunculus bupleuroides community [in crevices and between consolidated sandstone and syenit boulders, endemic in the Monchiquense sector, mesomediterranean, a dynamic transition from Asplenietea to Calluno-Ulicetea]
CISTO-LAVANDULETEA Br.-B1. in Br.-B1., Molinier \& Wagner 1940

+ Lavanduletalia stoechadis Br.-Bl. in Br.-Bl., Molinier \& Wagner 1940 em. Rivas-Martínez 1968 * Ulici argentei-Cistion ladaniferi Br.-Bl., Pinto da Silva \& Rozeira 1964

Cisto ladaniferi-Ulicetum argentei $\mathrm{Br}$ - $\mathrm{Bl}$., Pinto da Silva \& Rozeira 1964 em. Rivas-Martínez 1979 [thermo- and mesomediterranean Cistus-shrubland with Mediterranean and Ibero-Atlantic distribution] Genisto hirsutae-Cistetum ladaniferi Rivas Goday $1954 \mathrm{em}$. Rivas-Martínez 1979 [Cistus-shrubland on relatively nutrition-rich, siliceous soils, LusoExtremadurense province]

Erico australis-Cistetum populifolii Rivas Goday 1954 [Bajo-Alentejano-Monchiquense sectors, mesomediterranean, subhumid bioclimate, transitional association between the CistoLavanduletea and the Calluno-Ulicetea]

ACKNOWLEDGEMENTS. The financial support by the German Research Foundation (DFG) is greatly acknowledged (Az. De 402/3). We thank the administration of the "Parque Natural de los Alcornocales" for the permission to study the populations in the Andalusian Mountains and two anonymous reviewers for valuable remarks. We are indebted to R.J. Byer for the linguistic correction and to A. Galán de Mera for valuable remarks and the translation of the Spanish abstract.

\section{BIBLIOGRAPHY}

ARROYO, J. \& T. MARAÑóN - 1990- Community ecology and distributional spectra of Mediterranean shrublands and heathlands in Southern Spain. J. Biogeography 17: 163-176. ASENSI, A. y B. DÍEZ GARRETAS - 1987 Andalucia occidental. In: Peinado Lorca M. \& S. Rivas-Martínez (eds.) La Vegetacion de España: 197-230. Alcalá de Henares.

BARKHAM, J.P. -1980- Population dynamics of the wild daffodil (Narcissus pseudonarcissus). I. Clonal growth, seed reproduction, mortality and the effects of density. J. Ecol 68: 607-633.

BOESEWINKEL, F. D. -1989- Ovule and seed development in Droseraceae. Acta Bot. Neerlandica 38: 295-311.

BRAUN-BLANQUET, J. -1964Pflanzensoziologie. Grundzüge der Vegetationskunde. $3^{\text {rd }}$. Edit., Berlin, Wien, New York. 
BRAUN-BLANQUET, J., A.R. PINTO DA SILVA \& A. ROZEIRA -1964- Résultats de trois excursions géobotaniques à travers le Portugal septentrional et moyen - III Landes à Cistes et Ericacées (Cisto-Lavanduletea et CallunoUlicetea). Agronomia Lusitana 23: 229-313.

CHEERS, G. -1992- Lett's Guide to Carnivorous plants of the World. London.

DEIL, U. -1997a- Zur geobotanischen Kennzeichnung von Kulturlandschaften. Erdwissenschaftliche Forschung Vol. 36. Stuttgart.

DEIL, U. -1997b- Distribution and ecology of some rare plant species in Northern Morocco I: Teucrium afrum ssp. rubriflorum and Euphorbia transtagana. Acta Bot. Malacitana 22: 250-254.

DIERSCHKE, H. -1994-Pflanzensoziologie. Grundlagen und Methoden. Stuttgart.

GALÁN DE MERA, A., U. DEIL, J.A. VICENTE ORELLANA \& I. SÁNCHEZ GARCÍA. -1996Nothobartsia aspera (Scrophulariaceae): nuevas localidades, ecología y fitosociología. Acta Bot. Malacitana 21: 309-310.

GALÁN DE MERA, A. \& J. A. VICENTE ORELLANA - 1996- Phytosociological study of the plant communities with Stauracanthus boivinii of the SW of the Iberian Peninsula and NW of Africa, using multivariate analysis. Bot. Helv. 106: 45-56.

GARRIDO DÍAZ, B. y J. M. ORTIZ HERRERA 1996- Introducción a la biología de Drosophyllum lusitanicum (L.) Link. Almoraima 15: 233-243.

GIL JIMÉNEZ, Y., P. NAVAS FERNÁNDEZ, D. NAVAS FERNÁNDEZ, A.V. PÉREZ LATORRE y J.M. NIETO CALDERA -1996Tipos de hábitats naturales contemplados en la directiva 92/43 C.E.E. presentes en el Campo de Gibraltar y espacios naturales de interés para su conservación. Almoraima 15: 255-266.

HOLDEREGGER, R. -1996- Reproduction of the rare monocarpic species Saxifraga mutata $\mathrm{L}$. Bot. J. Linnean Society 122: 301-313.

HOLDEREGGER, R. - 1997- Intrapopulational size structure of the monocarpic species Saxifraga mutata and its relationsship to succession. Flora 192: 151-156.

KOPECKY, K \& S. HEJNY -1974- A new approach to the classification of anthropogenic plant communities. Vegetatio 29: 17-20.
KROHMER, J. \& U. DEIL -1999. Landnutzungswandel in der Serra de Monchique (Südportugal) in Abhängigkeit von natürlichen und anthropogenen Bedingungen. Geoökodynamik 20: 169-192.

MALATO BELIZ, J. -1982- A Serra de Monchique. Flora e Vegetação. Colecção "Parques Naturais”, Vol 10. Serviço Nacional de Parques, Reservas e Património Paisagístico. Lisboa.

NEZADAL, W., DEIL U. \& W. WELSS -1994Karte der aktuellen Vegetation des Campo de Gibraltar (Provinz Cádiz, Spanien). Hoppea, Denkschrift Regensb. Bot. Ges. 55: 717-756.

NIETO CALDERA, J.M, A.V. PÉREZ LATORRE y B. CABEZUDO -1990- Datos sobre la vegetación silicícola de Andalucía I. Acta Bot. Malacitana 15: 179-192.

OCAÑA, M.E., B. VALDÉS, E. MORENO SOCÍAS y R. PARRA -2000-Drosophyllum lusitanicum (L.) Link. In: G. Blanca et al. (eds.) Libro Rojo de la Flora Silvestre Amenazada de Andalucía. Tomo II. Especies Vulnerables. Consejería de Medio Ambiente. Junta de Andalucía. Sevilla. OJEDA, F., ARROYO J. \& T. MARAÑÓN -1995Biodiversity components and conservation of Mediterranean heathlands in southern Spain. Biological Conservation 72: 61-72.

OJEDA, F., T. MARAÑÓN \& J. ARROYO-1996aPatterns of ecological, chorological and taxonomic diversity at both sides of the Strait of Gibraltar. J. Veg. Science 7: 63-72.

OJEDA, F., T. MARAÑÓN \& J. ARROYO -1996bPostfire regeneration of a Mediterranean Heathland in Southern Spain. Int. J. Wildiand Fire 6: 191-198.

ORTEGA OLIVENCIA, A. O., J. P. CARRASCO CLAVER \& J. A. DEVESA ALCARAZ -1995Floral and reproductive biology of Drosophyllum lusitanicum (L.) Link (Droseraceae). Bot. J. Linnean Society 118:331351.

PÉREZ LATORRE, A.V., J.M. NIETO CALDERA y B. CABEZUDO - 1993- Contribución al conocimiento de la vegetación de Andalucía II. Los Alcornocales. Acta Bot. Malacitana 18: 223-258.

PÉREZ LATORRE, A.V., J. M. NIETO CALDERA y B. CABEZUDO -1994- Datos sobre la vegetación de Andalucía III. Series de vegetación caracterizadas por Quercus suber 
L.. Acta Bot. Malacitana 19: 169-183.

PÉREZ LATORRE, A. V., A. GALÁN DE MERA,

U. DEIL y B. CABEZUDO - 1996- Fitogeografía y vegetación del sector Aljíbico (Cádiz-Málaga, España). Acta Bot. Malacitana 21: 241-267.

PÉREZ LATORRE, A.V., A. GALÁN DE MERA, P. NAVAS, D. NAVAS, Y. GIL y B. CABEZUDO -1999- Datos sobre la flora y vegetación del Parque Natural de los Alcornocales (Cádiz-Málaga, España). Acta Bot. Malacitana 24: 133-184.

QUÈZEL, P., M. BARBERO, A. BENABID, R. LOISEL \& S. RIVAS-MARTÍNEZ -1988Contribution à l'étude des groupements préforestiers et des matorrals rifains. - Ecologia Mediterranea 14: 79-122.

RIVAS-MARTÍNEZ, S. -1979- Brezales y jarales de Europa occidental (Revisión fitosociológica de las clases Calluno-Ulicetea y CistoLavanduletea). Lazaroa 1: 5-127.

RIVAS-MARTÍNEZ, S., M. LOUSA, T.E. DÍAZ, F. FERNÁNDEZ-GONZÁLEZ y J.C. COSTA 1990- La vegetación del sur de Portugal (Sado, Alentejo y Algarve). Itinera Geobotanica 3: 5126.

RUDNER, M., U. DEIL \& A. GALÁN DE MERA 1999-Zwergbinsengesellschaften im Südwesten der Iberischen Halbinsel. Mitt. Bad. Landesver. Naturkunde u. Naturschutz N.F., 17 (2) : 427 448.

SACHS, L. -1993-Statistische Methoden. Planung und Auswertung. $7^{\text {th }}$. Ed.. Berlin.

SENG, M. \& U. DEIL, -1999- Forest vegetation types in the Serra de Monchique (Portugal): Anthropic changes of Oak forests. Silva Lusitanica 7: 71-92.

SILVERTOWN, J., M. FRANCO, I. PISANTY \& A. MENDOZA -1993-Comparative plant demography - relative importance of life-cycle components to the finite rate of increase in woody and herbaceous perennials. J. Ecol. 81: 465-476.

VALDÉS, B. -1996- El elemento endémico en el Campo de Gibraltar. Almoraima 15: 13-33.

VALDÉS, B., S. TALAVERA \& E. FERNÁNDEZGALIANO (eds.) -1987- Flora Vascular de Andalucía Occidental. vol. I-III. Barcelona.

WER NER, P.A. \& H. CASWELL - 1977- Population growth and age versus stage-distribution models for teasel (Dipsacus sylvestris Huds.). Ecology 58: 1103-1111.

WILLIAMS, S.E., V.A. ALBERT \& M.W. CHASE -1994-Relationships of Droseraceae: a cladistic analysis of rbcl sequenced morphological data. Am. J. Bot 81: 1027-1037.

Aceptado para su publicación en junio de 2001

Address of the authors. J. MÜLLER: Botanical Institute, Geobotany und Plant Ecology, University of Frankfurt, Siesmayerstr. 70, B.P. 1119 32, D 60054 Frankfurt, Germany. E-Mail: Jonas.Mueller@em.uni-frankfurt.de; U. DEIL: Institute of Biology II, Department of Geobotany, University of Freiburg, Schänzlestr. 1, D - 79104 Freiburg, Germany. E-Mail: deil@pop3.unifreiburg.de 